\title{
The religious roots of racism in the Western world: A brief historical overview
}

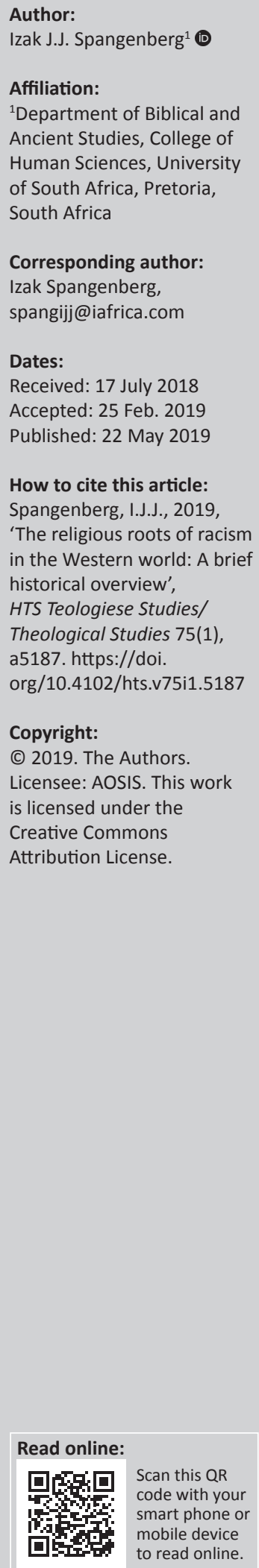

Racism is again a burning issue in our country. One may define racism as the conviction that not all humans are equal, but that some are 'worthier' than others. Usually those who are regarded as 'unworthy humans' are not treated on par with the rest. The 'othering' of humans in the Western world did not commence in the 16th, 17th, 18th or 19th centuries. It is argued that the roots of racism in the Western world date back to the 1st century CE when the early Christians severed their ties with the Jewish people and their religion, and started humiliating and denigrating them. Traces of this can be found in the New Testament in inter alia John 8:44, Revelation 2:9 and 3:9. The Jewish people and their synagogues were associated with the Devil. However, Paul also contributed to the anti-Judaism sentiments of early Christians. He argued that the gospel superseded the law. This eventually led to the conviction that Christianity superseded Judaism, and that Jews and Judaism ranked lower than Christians and Christianity. These beliefs created fertile soil for the development of racism in the Western world. The article presents a brief overview of the history of Christianity, how it developed, how it became the state religion of the Roman Empire and the dominant religion in the Western world, and how the religious convictions fed into the sociopolitical and economic policies of the Western world. The article delivers a plea for accepting the view that all religions are human constructs and that their adherents need to meet the 'other' on an equal footing. The Western world especially needs to look at how Christianity contributed to the way it treated other people during the course of history.

Keywords: Augustine; Christianity; Judaism; Islam; Racism; Skin colour; Western world.

People of African descent have suffered slavery, persecution, and discrimination in Christian nations for centuries. (Hill \& Cheadle 1996:64)

The association of white with purity, virtue, and Christ, and black with impurity, evil, and the devil, pervades the Christian liturgy and popular belief. (Jablonski 2012:158)

\section{Foreword}

When Christina Landman and I were born in the early fifties of the previous century, the National Party was already in power in South Africa for a few years. We were born in a country whose government introduced legislation to differentiate between people and believed that the different pigmented ${ }^{1}$ citizens should be kept separate and preferably not allowed to socialise with one another. There should thus be separate amenities for them. Park benches had signs on to indicate who is allowed to sit on them, and government offices had different doors with signposts indicating who is allowed to enter through which door. Public toilets also had signs on their doors, indicating who is allowed to use them. There were separate buses and trains for the different pigmented people to travel around town and around the country. When there was only one bus or one train to travel with, the darker skinned ones had to sit apart from the lighter skinned. In some buses, the darker skinned people had to sit at the back, or even stand while travelling. Some trains had special coaches for darker skinned people. There were also separate schools and universities, separate suburbs and even separate pedestrian bridges! Sections of the South African coastline were also assigned to the different pigmented citizens as beaches where they may bathe. Bathing in a beach not assigned to your 'group' could lead to a fine (Morris 2012:45-46; Welsh 2010:52-57).

An enormous amount of legislation had been promulgated by the National Party before we were born, and more were introduced while we were growing up. When we commenced with our

1.l use the words 'pigmented citizens' to draw attention to the fact that a biological factor was used to rank people and to discriminate between them. Our skin colour merely reflects where our forebears lived on the Earth and why some have more melanin in their skin than others. Skin colour has nothing to do with character or intelligence.

Note: The collection entitled 'Christina Landman Festschrift', sub-edited by Wessel Bentley (University of South Africa) and Victor S. Molobi (University of South Africa). 
theological training in the early seventies of the previous century, apartheid was deeply entrenched in the South African society and in most churches as well. The denomination to which we belonged (the Dutch Reformed Church) had four different churches for the different pigmented Christians. There was one for 'whites', one for 'blacks', one for 'brown people' and one for people of Indian descent (De Gruchy 1979:1-101; Kinghorn 1986:86-143; Strauss 2015:58-60).

Although we studied at two different South African universities, many of our theological professors shared the same convictions concerning the apartheid policy. These professors were members of the 'Afrikaner Broederbond', which served as a think-tank for the National Party and its policies (Smith 2009:181-207; Wilkins \& Strydom 2012). They were convinced that the Bible supported such a policy. However, there was a small number of Afrikaans-speaking Reformed theologians who were convinced that one cannot use the Bible to support the apartheid policy (Jonker 1998; Naudé 1995). According to them, the Christian message is one of reconciliation and not of separation. However, none of them commented on Christianity's supersessionist theology and its ranking of religions.

I first met Christina on a postgraduate student tour to Germany and Switzerland in 1984. We eventually became colleagues when I joined the academic staff of the University of South Africa in 1987. She is well-known for her bold viewpoints concerning discrimination against women and for acting as spokesperson for those who bear the brunt of discrimination in our country, be it being of a different skin colour, HIV-positive, poor or in jail. Her knowledge of Church history and her willingness to take up the cudgels for those being discriminated against inspired the writing of this article in celebration of her retirement.

\section{Introduction}

Most Christians currently living in South Africa know about the use and abuse of the Bible to support the National Party's policies during the apartheid era (1948-1994) (Loubser 1987). However, not many of them are aware that apartheid was practised throughout the Western world and that the Bible was equally used and abused by other Christians to support their governments' discriminatory legislation and practices. The United States may serve as an example. Prior to the civil rights movement of the sixties of the previous century, similar practices were the order of the day in the United States. People with a darker skin colour suffered discrimination on a similar scale as in South Africa (Hill \& Cheadle 1996:10-12; 17-19; Jablonski 2012:150).

The conviction that people with a white skin are superior to people with dark skin is a fallacy that was cherished throughout the Western world for many centuries. Support for this fallacy was gained inter alia from the story of Noah's curse of Canaan, the son of Ham (Gn 9:20-27) (Day 2013:137-153; Stoop 1984:153-164). The reason for the curse was that Ham,
Noah's son, did not cover his father's nakedness after discovering him lying naked in his tent having had too many sips of his own wine. The curse reads as follows: 'Cursed be Canaan, slave of slaves shall he be to his brothers' (Gn 9:25). Earlier biblical readers assumed that Ham's descendants had dark skin as slaves normally had darker skin. However, there is no reason for this assumption in the biblical text, but we know from the rest of the Old Testament that Israelites were instructed to subdue and even to exterminate the Canaanites. As most slaves in the Western world came from countries where people had darker skin, this supported the assumption that dark-skinned people are descendants of Ham and Canaan (Jablonski 2012:142-156).

The article argues a case that the roots of racism in the West go further back than the period of colonisation, the practice of slavery and the ranking of people according to skin colour in the Western world. The roots of racism in the Western world can be traced back to the last years of the first and the early decades of the second century when early Christianity broke away from Second Temple Judaism. The break with early Judaism gave birth to the conviction that Christianity superseded Judaism. A brief overview of the history of Christianity will serve as evidence for the argument that Christianity's supersessionist theology, its anti-Judaism sentiments and its labelling of Jews contributed to the origin and development of racism in the Western world. The supersessionist theology also impacted Christians' view of Islam and their relationship with Muslims.

The body of the article consists of five sections in which the history of Christianity and its supersessionist theology, which fed into the idea of racial superiority in the Western world, are narrated. It commences with the history of early Christianity, then follows a section on the Byzantine period before the Middle Ages is discussed. The fourth section concerns the Protestant Reformation and the views of some reformers before the period of Western colonisation of the world and the role that Christianity played in ranking people.

\section{From early beginnings to becoming state religion}

It has become a truism among biblical scholars that Jesus had nothing to do with the origin of Christianity. He was a Jew, and his message concerned the kingdom of God (Den Heyer 1996:80-82; Flusser 1988:614-677; Harlow 2010:257-259; Horsley 2003:55-78; Le Donne 2011:72-93; Luttikhuizen 2006:11-22; Tatum 2009:xiv-xviii; Vermes 2013:1-60). He cherished the hope that Yahweh will once again establish his reign in Palestine and that this will translate into a more equitable society where common folk will not be ruled, taxed and exploited by foreign powers.

The Romans took control of Palestine after $63 \mathrm{BCE}$ and systematically introduced a harsh tax system, which had a devastating impact on the small farmers living in Palestine. ${ }^{2}$ 2.In the words of Armstrong (2014:212): "In any traditional empire, the purpose of government was not to guide or provide services for the population but to tax them'. 
As the years passed, the hope grew that Yahweh will liberate them from foreign oppression. Jesus, the prophet from Galilee, stepped into this context and delivered a message that gave people hope that the end of the oppression is not far off. However, when he cleansed the temple in Jerusalem (30 $\mathrm{CE}$ ), the Romans realised that something had to be done before a full-fledged rebellion started. They stepped in and crucified Jesus to drive home the message that whoever challenged Roman rule in Palestine will pay a price. Although Jesus was not the first Jew to suffer this fate, his death had an outcome that nobody envisaged at that stage.

The crucifixion of Jesus impacted on the convictions of his followers, and they had to readjust the belief that Jesus would inaugurate God's kingdom. A small group made themselves at home in Jerusalem and kept his memory and his message alive. Jerusalem soon became the headquarters of the Jesus movement, which remained Jewish until the Romans suppressed the First Jewish Rebellion (66-70 CE). The rebellion erupted in $66 \mathrm{CE}$, and the Roman soldiers stationed in the fortress Antonia near the temple were driven out of Jerusalem. The outcome of this was that 'the country was (...) temporarily free of imperial control' (Horsley 2003:36). It took the Romans almost 4 years to re-establish their presence in Jerusalem again. They ransacked Jerusalem and the temple and drove out all the rebellious groups from the city. Members of the Jesus movement had to flee as well. They settled in Syria and then severed their ties with the 'Pharisaic reform movement', which made Yavne (a coastal town in Palestine) their headquarters (Trocmé 1997:83-84). The break between the Jewish followers of Jesus and the followers of the Pharisee reform group is reflected in texts like John 8:44 and Revelation 2:9, 3:9 in which the Jews are labelled 'children of the Devil' and their meetings 'synagogues of Satan'. ${ }^{3}$

Although Eliav (2006:569) warns scholars not to project 'the medieval picture of two diametrically opposed religions separated by a theological abyss, not to mention hostility, loathing and violence backwards into the Roman period', there is ample evidence that 'Christianity understood itself more or less as the heir of Judaism and as its true expression' (Flusser 1988:617). This contributed to the tension that developed between the two groups during the first and second centuries. There were no physical attacks on Jews and their properties during these centuries, but Christian authors started denigrating Jews and their understanding of what Judaism entails. Flusser is correct in his judgement that ' $[w]$ hile antisemitism existed [in the Roman Empire] before Christianity, Christian anti-Judaism was far more virulent and dangerous' (Flusser 1988:617).

The early Christians did not consist only of Jews but also of non-Jewish people. Paul played a prominent role in opening the doors for non-Jewish people to join the Jesus movement

3.Scholars differ on the date of the "parting of the ways' between Judaism and Christianity. 'Some see it occurring, at least in nuce, as early as Jesus' own career; others date it to the time of the First Jewish Revolt in 66-70 or to the Bar Kokhba Revolt of 132-135 CE. More recently, some have pushed it as late as the fifth and even sixth century (Harlow 2010:274). I prefer to go along with Trocme who argues that the parting of the ways occurred towards the end of the first century. Christians stopped engaging in polemics with people born Jewish and presented themselve as authentic Jews (Trocmé 1997:112). and to regard themselves as 'children of Abraham' (Vermes 2013:87-114). 'Paul taught an eschatological form of Judaism in which, as part of God's design for the last days, faithful Gentiles were included among the people of Israel' $^{\prime}$ (Galambush 2012:147). He devalued circumcision, the dietary laws and the Sabbath and argued that by believing in Jesus, non-Jews became children of Abraham. They need not follow the Jewish way of life and their cultural and religious practices (Gl 3-4; Rm 4-6). A central theme in Paul's theology is 'supersession of the law by the gospel' (Barton 2007:77). However, it was not only Paul that played a part in the development of the nascent Christian religion. The author of the Gospel of John, the author of the Letter to the Hebrews and the author of the Book of Revelations contributed to the development of a belief that presented itself as the heir of Judaism (Räisänen 2010:264-282; Trocmé 1997:102-112).

As time passed, Paul's conviction that the gospel superseded the law developed into a supersessionist theology: the belief that Christianity superseded Judaism. ${ }^{4}$ However, the Romans still regarded Christianity as an aberration of Judaism and did not view it as an authentic religion that should be permitted in the empire (Galambush 2012:153; Saperstein 1989:5). This situation changed dramatically when Emperor Constantine (275-337) converted to Christianity and declared it a permitted religion of the Roman Empire. Three religions now qualified to be labelled as licit: Christianity, paganism and Judaism. Emperor Theodosius I (346-395) went further and declared Christianity the only official state religion of the Roman Empire and decreed pagan temples to be destroyed and heretics to be punished and their books burnt.

From the time that Christianity became the state religion of the Roman Empire onwards, the conviction that Christianity superseded Judaism grew stronger, and all kinds of legislation were introduced to promote Christianity and to prevent Judaism from attracting converts.

\section{Christians and Jews after 400 CE}

The first three centuries of the Christian era were dominated by discussions concerning the relationship between the humanity of Jesus and his divinity, and how one should understand the relationship between him and God. Was he an ordinary human being whom God adopted as his son; was he a heavenly being on par with God; was he God's first creation, or was he God incarnate? The different views were responsible for some heated debates and even the labelling of other Christians as 'schismatics' or 'heretics'. However, Emperor Constantine (275-337) wished to put an end to this when he converted to Christianity. He called the Christian bishops together and instructed them to come to a final decision concerning Jesus' identity and status. Constantine was convinced that unity among Christians could contribute to the unity of the Roman Empire (Harari 2014:238; Noll 2012:42-43).

4.The view that Marcion (died 160) expressed, namely, that Christianity should take leave of the Old Testament as it is 'the revelation from an evil deity' (Barton leave of the Old Testament as it is 'the revelation from an evil deity' (Barton
2007:74) may be classified as merely an extremist position, but it was in line with the developments in early Christianity. 
The First Ecumenical Church Council met at Nicaea in 325. After some deliberations and with the assistance of the emperor himself, the delegates decided on the following answer: Christ was the 'only begotten Son' of the Father and 'of the same being' (homoousios) as the Father (Küng 1995: 176-196). The Nicene Creed formulated Jesus' divinity in no uncertain terms, and he was recognised as one of the persons of the Holy Trinity who existed from eternity (Veyne 2010:107-122).

The conviction that Jesus Christ was divine and one of the persons of the Holy Trinity was reaffirmed at the Second Ecumenical Council held at Constantinople in 381. The assembled bishops, who met under the auspices of emperor Theodosius I, slightly modified some sections of the original Nicene Creed. The updated version 'expanded the section on Christ's birth and his suffering under Pilate, included minor modifications in some of the wording from 325, and produced a fuller statement on the Holy Spirit' (Noll 2012:51). Scholars therefore prefer to refer to the creed not as the 'Nicene Creed' but rather as the 'Nicene-Constantinopolitan Creed'.

The two ecumenical councils mark the point where the 'parting of the ways' reached a stage where Christianity could no more be labelled an 'aberration' or a 'sect' of Judaism. It became a distinct religion and its monotheism differed radically from the monotheism of Judaism. Although some Christians may be offended by the following remark, it does convey some truth: 'The Trinity just marks the point where Christianity stopped having much to do with the teaching of Jesus [the Jew] and modelled itself on contemporary pagan religion' (Hunt 2004:220).

When the Second Ecumenical Council met in Constantinople (381) 'a young man named Augustine (354-430) was teaching rhetoric in the North African city of Carthage' (Tatum 2009:44). He was barely 27 years old. He soon converted to Christianity, was baptised in 387 and eventually became bishop of Hippo in North Africa in 396. At that stage, Christianity was the official state religion of the Roman Empire, and the relationship between Christians and Jews was not a healthy one. Emperor Constantine harboured strong anti-Jewish sentiments and introduced legislation that made life difficult for the Jews:

\footnotetext{
Constantine allowed Jews access to the city of Jerusalem once a year - to bewail their fate; the city had been off limits to Jews since Hadrian's founding of Aelia Capitolina. Constantine provided that Jews who attempted by force to prevent the conversion of a co-religionist to Christianity were to be burned alive! Jews were not allowed to own Christian slaves, to circumcise any male slave in their possession or to make converts to their faith. (Pohlsander 2004:82)
}

Emperor Theodosius I intensified the repression. Apart from this, John Chrysostom (347-407) delivered sermons in which he castigated the Jews. One may call the atmosphere at this stage rather toxic, and questions like the following were the order of the day: 'Why are there still Jews if Christianity is the new Israel?' 'Should Jews be tolerated to co-exist with
Christians in the empire?' It is rather astonishing that Augustine stepped forward and tried to create space for the Jews (Fredrikson 2010). He published several books in which he expressed his views and argued that Jews should be permitted to live among Christians for the following reasons: (1) 'Jews were valuable first as the "guardians of scripture", and (2) 'Jews were living proof of the truth of Christian faith' (Saperstein 1989:9-10).

Concerning the first motivation, he argued that Jews could assist Christians in countering pagans' arguments that the Christian religion is of recent origin and that it lacks roots in the past. Concerning the second motivation, he argued that the Jews were suffering because they rejected Jesus as their Messiah. By being alive, Christians could see what the consequences are when one rejects God's offer of salvation. 'If Jews were to disappear from Christian society, this powerful lesson might be reduced to an easily overlooked antiquarian footnote' (Saperstein 1989:10; cf. also Van Oort 2009:356-357).

Augustine used the story of Cain and Abel (Gn 4:1-18) to buttress his argument (Van Oort 2009:357-359).

Both sons of Adam sacrificed to God, but only Abel's offering was accepted. Cain then turned on his brother and killed him. Augustine made use of typology to convey his message (Van Oort 2009:358). Cain stood for the Jews and Abel for Jesus Christ. Cain killed his brother, and God had to punish him. God made him a fugitive and wanderer on earth (Gn 4:12) but gave him a mark of identification and protection - the sign of circumcision (Van Oort 2009):

Volgens Augustinus geeft het teken van Kaïn bescherming en, zoals dat het geval was met Kaïn, geld ook nu: ieder die een Jood 'dood', dat wil zeggen: wie hem dwingt op te houden als Jood te leven, zal getroffen worden door Gods zevenvoudige wraak. (p. 359)

Augustine's theological arguments concerning the Jews guided many Christian leaders in the centuries following his death. However, the conviction that Christianity superseded Judaism (evidenced by the fact that it became state religion of the empire) eventually impacted negatively on the way Jews were treated during the later centuries of the Middle Ages.

\section{Christians, Jews and Muslims during the Middle Ages (500-1500)}

When Constantine converted to Christianity, he decided to make Byzantium, located on the Western shores of the Bosphorus, the eastern capital of the empire. He renamed it Constantinople, enlarged it and adorned it with Christian churches. The Roman Empire split into two after the death of Theodosius I in 395, and Constantinople became the capital of the eastern Roman Empire (also referred to as the Byzantine Empire). ${ }^{5}$ The Western Roman Empire progressively lost its

5.The split of the Roman Empire affected Christianity as well. Two forms of Christianity soon manifested: one with its centre in Rome and one with its centre in Constantinople. The inevitable schism occurred in 1054 
grip over large areas in Europe until Rome eventually fell to the barbarians in 476. The Byzantine Empire, on the other hand, had to defend itself against the aggression of the Sasanian Empire, which was located towards the east. The Sasanians tried to revive the ancient Persian Empire and moved their armies into Asia Minor, thus threatening the eastern part of the Byzantium Empire. One characteristic of the two empires should not go unnoticed - both were 'driven to universalism by a potent and unprecedented combination of strongly centralized political systems and zealous religious ideologies' (Cline \& Graham 2011:294).

When Justinian (527-565) came to the throne in Constantinople, he set himself the task of restoring the glory of the Roman Empire. 'He reconquered Italy, North Africa and southern Spain' (Montefiore 2012:192) but almost lost the eastern parts of the Byzantine Empire to the Sasanian Empire. He also set himself the task of supporting and promoting Christianity and built no less than 34 churches, including the famous church of Hagai Sofia in Constantinople. However, his eagerness to promote Christianity unfortunately had negative outcomes (Montefiore 2012):

Justinian demoted Judaism from a permitted religion and banned Passover if it fell before Easter, converted synagogues into churches, forcibly baptized Jews, and commandeered Jewish history: in 537, when Justinian dedicated his breathtaking domed Church of Hagia Sofia ('Holy Wisdom') in Constantinople, he is said to have reflected, 'Solomon, I have surpassed thee'. (p. 192)

With these acts, Justinian ignored Augustine's plea for tolerance towards the Jews. From now on, Jews knew that life under Christian rule will not be easy. There was, however, a brief period of respite for some Jews during the papacy of Gregory I (590-604). Jews in southern France requested their fellow Jews in Rome to submit a formal protest to Pope Gregory concerning baptism under duress. 'He responded in a letter to the bishops of Arles and Marseilles, gently admonishing that despite the noble purpose of winning new souls, force must not be sanctioned' (Saperstein 1989:15). After being baptised (willingly or unwillingly), Jews were regarded to be Christians and ecclesiastical court then had jurisdiction over them (Saperstein 1989):

Jews as Jews were entitled to observe all their ancient traditions without being disturbed; but a Jew who had been baptized and observed even a single Jewish practice or professed a single Jewish belief could be prosecuted, and burnt at the stake. (p. 15)

Although most early Medieval European rulers and popes did not follow this kind of practices, there was one exception - the 7th-century rulers of Spain. They followed a policy of compulsory baptism. In the rest of Europe, Jews lived in harmony with their Christian neighbours, although the latter were convinced that Judaism ranked lower than Christianity and that Jews should convert to Christianity to be saved.

In the beginning of the 7th century, there were three empires and three major religions in the Mediterranean and Near Eastern worlds. The empires were: the Western Roman Empire, the Eastern Roman Empire and the Sasanian Empire.
The religions practised in the empires were: Judaism, Christianity and Zoroastrianism respectively. However, towards the end of the 7 th century, there were still three empires but now four religions.

During the early decades of the 7th century, Muhammad, an Arabian prophet, experienced several revelations, which gave birth to a new monotheistic religion called Islam. The new religion was not totally new but based on what Muhammad had learnt from Jews and probably from Christians as well (Küng 2009:32-45). It is not strange to find stories in the Koran that reminds one of stories of the Hebrew Bible and/or Old Testament. An unidentified Jewish scholar once said that the similarities are not accidental as 'Islam is Judaism transplanted among the Arab people, whereas Christianity is Judaism transformed for the Gentile people' (Geering 2001:25).

Muhammad made Mecca the main centre of Islam in 630, and from there, he and his followers commenced with their missionary work and conquest of the Arabian peninsula (Cline \& Graham 2011:328). After his death in 632, his first successor, the Caliph Abu Bakr (632-634), continued the conquest of Arabia and later on moved into Palestine. The second successor, Caliph Umar ibn al-Khattab (634-644), succeeded in conquering Jerusalem in 638. After conquering the city, the armies of Umar continued their assault against the Byzantine and Sasanian empires. They soon conquered the Sasanian Empire, but the Byzantine Empire survived. The Byzantine Empire, however, remained one of their targets. Other Arabian armies went westwards, conquering Egypt and parts of North Africa (Cline \& Graham 2011:328). After a period of internal strife, the Umayyad caliphate succeeded in establishing themselves as the legitimate successor to the prophet. They made Damascus their capital and built two mosques in Jerusalem: the Dome of the Rock and the al-Aqsa. They eventually ruled over an area 'greater than that covered by the entire Roman Empire at its height' but did not force people to convert to Islam (Bokhari et al. 2012):

Christians, Zoroastrians and Jews were free to continue to follow their own religion so long as they paid a head tax to their new rulers. However, many conquered peoples chose to convert to Islam. Conversion was simple: the only requirement was that the new believer acknowledge formally that there is no God other than Allah and that Muhammad is his Prophet. (p. 44)

Christians living in the Byzantine Empire and in Europe regarded the Muslim conquests and Islam an enormous threat to their beliefs and labelled them 'infidels' who should be opposed, conquered and subdued. In 1096, Pope Urban II called on Western European knights to assemble and liberate the Holy Land from the Muslim infidels. This was the start of the First Crusade. ${ }^{6}$ Many joined in the march towards Palestine and Jerusalem. Although the pope did

6.At this stage in history, two distinct forms of Christianity existed - one in the west with Rome as centre and one in the east with Constantinople as centre. The West preferred Latin while the East preferred Greek as the official language of their preferred Latin while the East preferred Greek as the official language of their
liturgies and documents. The schism occurred in 1054 and was more politically and liturgies and documents. The schism
culturally than theologically driven. 
not mention the Jews, 'some Crusaders found it difficult to understand why one infidel should be destroyed and the other left in peace' (Saperstein 1989:17). Jews living in the Rhineland (Germany) soon became targets of the Crusaders. Some German bishops tried to protect the Jews in their diocese but could not always prevent the attacks on the Jews and their properties.

With the launch of the Second Crusade in 1148, German Jews again feared for their lives and property.

Bernard of Clairvaux (1090-1153) travelled to the Rhineland and appealed for their safety (Saperstein 1989:18-19). However, he was adamant that heretics and infidels should not be left in peace and therefore promoted and supported the Second Crusade.

There were eight crusades between 1096 and 1270, and all of them were launched from within the borders of Western Christianity. The main aim was to drive out the Muslims from Jerusalem and the Holy Land. This aim was never fully reached except during the First Crusade when a 'Christian kingdom' was established in Jerusalem. However, Sultan Saladin of the Ayyubid Empire recaptured Jerusalem in 1189 during the Third Crusade. The capital of the Christian kingdom of Jerusalem was then moved to Acre in 1191. On 18 May 1291, the armies of the Egyptian Mamluks conquered Acre and thus ended Christian presence in that part of the Mediterranean (Olivier 1983:42-43).

The crusades had more negative than positive outcomes as not only Muslims suffered but Jews and some Christians as well. 'Christian dissenters were dealt with as brutally as was the outside enemy. (...) For Jews, even more, the crusades were an unrelieved disaster' (Littell 2001:98). A violent and persecuting society came into existence during the last centuries of the Middle Ages (Armstrong 2014:201-202; Küng 1992:163-171; Saperstein 1989:14-25). Many European Jews experienced the wrath not of God but of Christians claiming to be the children of the all loving Trinitarian God. During these centuries, Jews were expelled from England, France, Spain and from German-speaking countries (Rattansi 2007:15). ${ }^{\text {? }}$

\section{The Protestant Reformation (1500-1600)}

Broadly speaking, the Middle Ages lasted from 500 to 1500. However, most historical scholars regard 1492 as the year that marked the end of the Middle Ages. This date is linked to Christopher Columbus' discovery of the Caribbean islands, which ended Europe's period of isolation and inward-living. Explorations to the 'New World' broadened Europeans' worldview and challenged existing ideas. 'Instead of focusing on the preservation of past achievements, Western people were acquiring the confidence to look to the future' (Armstrong 2014:218).

7.Some scholars attribute the outbreak of anti-Judaism in the Middle Ages to the outbreak of anti-Islamism during the Crusades. 'The Jews were now lumped in with the Muslims' (Küng 1992:163).
Not many years after the discovery of the New World, the Catholic Church was rocked by individuals calling for a reformation of the church. Martin Luther (1483-1546), a German-speaking Augustinian monk, played a prominent role in what became known as the Protestant Reformation. He wrote 95 theses, which challenged inter alia the sale of indulgences to pay for the building of the St Peter's Cathedral in Rome.

Indulgences were documents promising forgiveness and thus a reduction of time spent in purgatory after death (Kennedy 2006:49). He also challenged the way the church treated its lay members and that Latin remained the official language of communication in the church. Ordinary people did not always understand the communication and could not read the Bible in their mother tongues. He was excommunicated in 1521 but then called on the German princes to reform the church themselves. It is today acknowledged that were it not for the German princes, the Reformation would not have succeeded (Küng 1995:558-566).

The Jews in Europe who were bystanders took note of the events and hoped that it will contribute to a better life for them. A split in Western Christianity may after all not be that bad (Eckardt 1989:42-43). One of the reasons why they took interest in the Reformation was the Reformers' emphasis on the study of the Bible - especially studying it in the original languages (Hebrew and Greek). The Reformers consulted Jewish rabbis and studied with them to get a better understanding of the scriptures.

Throughout all the years, Christian leaders cherished the hope that Jews will convert to Christianity. Luther was convinced that the Reformation will attract Jews as Christian leaders were once again studying the Hebrew Bible and were convinced that its prophecies were fulfilled in Jesus Christ (Littell 2001:190). He also believed that he was living in the end times and that a mass conversion of Jews might occur during his lifetime. Having studied Augustine's writings and his views on the Jews, Luther was at first positively inclined towards them and even wrote a tract with the title 'That Jesus Christ was born a Jew' (1523) to convince Christians to treat Jews better and to be tolerant of them. However, the Jews did not convert to the 'reformed church' and the way it interpreted the Old Testament/Hebrew Bible. Luther became disillusioned with them, changed his views and wrote a vicious anti-Semitic tract with the title 'On the Jews and Their Lies' (1543). ${ }^{8}$ It was evident that the Reformation could no longer be seen 'as a movement of return to the Jewish foundations of Christianity, but as a casting off of the restraints that had safeguarded the Jews for centuries' (Saperstein 1989:36).

Since the 17th century, Christians had to reckon with Muslim believers who challenged their beliefs and whose successors threatened to conquer Europe. During the reign of the Umayyads (eighth century) Islamic armies managed to 8.According to Littell (2001:190), the Nazis re-issued the tract 18 times during the Third Reich, while the Lutheran churches never republished it. 
conquer the Iberian Peninsula and then to move into France. However, an Islamic army of some 80000 men was defeated near Tours on 10 October 732. After this defeat, 'Muslims abandoned attempts at northward expansion and settled in the Iberian Peninsula, where they maintained a presence until 1492' (Bokhari et al. 2012:45). The year 1492 should thus not only be associated with the discovery of the New World but also with the expulsion of Jews and Muslims from the Iberian Peninsula.

Although the Muslims were systematically driven out of the Iberian Peninsula, a Muslim Turkish state originated in Anatolia in the 13th century. It rapidly expanded to become the Ottoman Turkish Empire, 'the most dynamic military power in Europe, Western Asia and North Africa in the 14th, 15th and 16th centuries' (Times Books 2006:96). After many years and many attempts, the empire eventually succeeded in capturing Constantinople in 1453. This caused consternation among Christians in the West. During the Reformation, the Ottoman Empire extended its borders in the Balkans and soon threatened the city of Vienna. Sultan Suleiman the Magnificent (1520-1566) besieged the city in 1529 , but his forces were unable to capture it. Jews in Europe were often accused of collaborating with Muslims to undermine European authorities. The fact that the Ottomans welcomed Jewish refugees expelled from Europe contributed towards these accusations. It is thus not strange that Luther also wrote tracts condemning the Turks (Edwards 2003:202).

\section{Colonisation of the world (1530-1950)}

A period of colonisation followed Columbus's discovery of the New World in 1492. It started with Spanish and Portuguese explorations of the Americas and eventually led to the establishment of their mercantile empires (Terreblanche 2014:195-211). These empires laid claim to areas where their ships had anchored and their sailors started trading with the indigenous people. Initially, these two countries tried to prevent other European countries from competing with them, but they were unsuccessful. England, France and the Dutch Republic eventually established their own mercantile empires in the 16th and 17th centuries and, like the Spaniards and Portuguese, became extremely wealthy by exploiting their colonies (Harari 2014:315-325).

The colonisation of other continents brought Europeans into contact with people with different skin colours, and they soon labelled them as of lower rank. Their experience with Jews in Europe and their Christian convictions contributed to this ranking and labelling. Hergesell (2006), in his article on race and racism, mentions a Spaniard named Gregorio García, who justified the Spanish conquest of Latin America 'on grounds that "the Indians" were of Jewish origin: after all, like the Jews, they were "slothful, believed not in the miracles of Jesus Christ, and were not grateful to the Spaniards for all the good offered them"'.

Terreblanche is of the opinion that '[i]n the first pattern of Western European empires (1530-1820), the myths about the alleged superiority/inferiority of the West/Rest were mainly religious constructs' (2014:125). He refers specifically to the role that missionaries played in propagating the conviction that Christianity is superior to other religions and that this idea created fertile soil for denigrating others. During the second pattern of the Western European empires (1820-1950), full-blown racist ideas were used to legitimise European domination of other people. The viewpoint that 'certain ethnic nations' were superior to others because they were more rational and civilised justified the new version of imperialism (Terreblanche 2014:124). However, the foundation for discrimination was laid during the first pattern of imperialism and this fed into the convictions of the second pattern. Many pages later in his book, Terreblanche (2014) quite correctly states the following:

As several missionary organisations played a pioneering role in the colonisation of Africa, it is not surprising that Social Darwanism claimed that God created a racial hierarchy in which white (or European) people were at the top and superior, and that black peoples of the different non-European continents were lower down on the social scale, ... (p. 353)

Concerning the colonising of the Muslim world during the 19th century, Hillenbrand (2015:53) writes as follows: 'The stereotypes formed in medieval times continued to prevail in the 19th century when Christian Europe began to colonize the Muslim world'. Christian anti-Judaism, its anti-Semitism and its denigration of Muslims of medieval times gave birth to racism, which flourished during the period of colonisation. The 'hierarchising' of religions contributed to the 'hierarchising' of people. Christianity and Europeans rank at the top, while other religions and other people are of lower rank.

Although many colonies became independent after 1950, the conviction of European superiority is still alive, and it will take many decades and concerted effort to eradicate this conviction and to treat all people on the same level.

\section{Conclusion}

Some scholars opine that it was only in the 1850s that the notion of white racial superiority emerged, while others state that the term 'racism' was coined around 1930 to counter the Nazis' conviction that they belong to a 'superior race' (Rattansi 2007:4). The previous sections present a slightly different picture. Rattansi is correct in stating that the term 'racism' only emerged with the surfacing of the Nazi racial ideology, but one cannot ignore the fact that Christians' supersessionist theology contributed to the conviction of the Europeans that they rank higher than the rest of humanity. Kelley summarises this excellently with the following remarks concerning racial thinking of Europeans (Kelley 2002):

Racial thinking also tends to assume, either explicitly or implicitly, a racial hierarchy. In this racial hierarchy Europeans are on top, Oriental and Semites are in the middle, and 'savages' (the Africans and the indigenous populations) are on the bottom. (p. 31) 
The history of Western Christianity evidences the conviction that Christians regard themselves as being superior to humans cherishing other religious convictions. The 'hierarchising' of religions usually contribute to the 'hierarchising' of humans. As long as Christians are convinced that their religion is superior to other religions, racial discrimination will remain part of our society. However, when believers are confronted with the good and the bad in the history of Christianity, things may change for the better. Making history a compulsory school subject (as the Minister of Education envisages) may contribute to a better South African society.

I am of the opinion that Christina Landman's study of Church history enabled her to play the role of carer, counsellor and spokesperson for those who are at the receiving end of violence, discrimination and exploitation in the South African society.

\section{Acknowledgements Competing interests}

The author declares that he has no financial or personal relationship(s) that may have inappropriately influenced him in writing this article.

\section{References}

Armstrong, K., 2014, Fields of blood: Religion and the history of violence, The Bodley Head, London.

Barton, J., 2007, 'Marcion revisited', in J. Barton (ed.), The Old Testament: Canon, literature and theology, pp. 67-81, Ashgate, Hampshire.

Bokhari, R., Seddon, M. \& Phillips, C., 2012, An illustrated history of Islam, Southwater, Leicestershire.

Cline, E.H. \& Graham, M.W., 2011, Ancient empires: From Mesopotamia to the rise of Islam, Cambridge University Press, Cambridge.

Day, J., 2013, 'Noah's drunkenness, the curse of Canaan, Ham's crime, and the blessing of Shem and Japheth', in J. Day (ed.), From creation to Babel: Studies in Genesis 1-11, pp. 137-153, T\&T Clark, London.

De Gruchy, J.W., 1979, The church struggle in South Africa, David Philip, Cape Town. Den Heyer, C.J, 1996, Jesus matters: 150 years of research, SCM, London.

Eckardt, A.L., 1989, 'The reformation and the Jews', Shofar 7(4), 23-47.

Edwards, M.U., 2003, 'Luther's polemical controversies', in D.K. McKim (ed.), Cambridge companion to Martin Luther, pp. 192-205, Cambridge University Press, Cambridge.

Eliav, Y.Z., 2006, 'Jews and Judaism 70-429 CE', in D.S. Potter (ed.), A companion to the Roman Empire, pp. 565-586, Blackwell Publishing, Oxford.

Flusser, D., 1988, 'The Jewish-Christian schism', in D. Flusser (ed.), Judaism and the origins of Christianity, pp. 617-644, Magnes, Jerusalem.

Fredrikson, P., 2010, Augustine and the Jews: A Christian defense of Jews and Judaism (with a new postscript), Yale University Press, New Haven, CT.

Galambush, J., 2012, 'Early Christianity in a Jewish context', in A.T. Levenson (ed.), The Wiley-Blackwell history of Jews and Judaism, pp. 142-155, Wiley-Blackwell, Chichester.

Geering, L., 2001, Who owns the Holy Land? St Andrew's Trust, Wellington, NZ. Harari, Y.N., 2014, Sapiens: A brief history of humankind, Harvill Secker, London.
Harlow, D.C. 2010, 'Early Judaism and early Christianity', in J.J. Collins \& D.C. Harlow (eds.) The Eerdmans dictionary of early Judaism, pp. 257-278, Eerdmans, Grand Rapids, MI.

Hergesell, B., 2006, 'Race/racism', in The Brill dictionary of Religion, BrillOnline.com, viewed 11 May 2018, from http://0-dx.doi.org.oasis.unisa.ac.za/10.1163/1872 5287_bdr_COM_00380.

Hill, J. \& Cheadle, R., 1996, The Bible tells me so: Uses and abuses of Holy Scripture, Anchor Books, New York.

Hillenbrand, C., 2015, Islam: A new historical introduction, Thames \& Hudson, London. Horsley, R.A., 2003, Jesus and empire: The Kingdom of God and the new world disorder, Fortress, Minneapolis, MN.

Hunt, J., 2004, Bringing God back to earth: Confessions of a Christian publisher, O-Books, Winchester.

Jablonski, N.G., 2012, Living color: The biological and social meaning of skin color, University of California Press, Berkeley, CA.

Jonker, W.D., 1998, Selfs die kerk kan verander, Tafelberg, Kaapstad.

Kelley, S., 2002, Racializing Jesus: Race, ideology and the formation of modern biblical scholarship, Routledge, London.

Kennedy, P., 2006, A modern introduction to theology: New questions to old beliefs, I.B. Tauris, London

Kinghorn, J. (ed.), 1986, Die NG Kerk en Apartheid, Macmillan, Johannesburg.

Küng, H., 1992, Judaism, SCM, London.

Küng, H., 1995, Christianity, SCM, London.

Küng, H., 2009, Islam: Past present and future, Oneworld, Oxford.

Le Donne, A., 2011, Historical Jesus: What can we know and how can we know it? Eerdmans, Grand Rapids, MI.

Littell, F.H., 2001, Historical Atlas of Christianity, Continuum, London.

Loubser, J.A., 1987, The Apartheid Bible: A critical review of racial theology in South Africa, Maskew Miller Longman, Cape Town.

Luttikhuizen, G.P., 2006, Veelvormigheid van het vroegste Christendom, Damon, Budel. Montefiore, S.S., 2012, Jerusalem: The biography, Weidenfeld \& Nicolson, London. Morris, M., 2012, Apartheid: An illustrated history, Jonathan Ball, Jeppestown.

Naudé, B., 1995, My Land van Hoop: Die lewe van Beyers Naudé, Human \& Rousseau, Kaapstad.

Noll, M.A., 2012, Turning points: Decisive moments in the history of Christianity, Baker Academic, Grand Rapids, MI.

Olivier, J.P.J., 1983, Akko: Spieëlbeeld van beskawings, NG Kerk-uitgewers, Kaapstad. Pohlsander, H.A., 2004, The Emperor Constantine, Routledge, London.

Räisänen, H., 2010, The rise of Christian beliefs: The thought world of early Christians, Fortress, Minneapolis, MN.

Rattansi, A., 2007, Racism, Oxford University Press, Oxford.

Saperstein, M., 1989, Moments of crisis in Jewish-Christian relations, SCM, London.

Smith, N., 2009, Die Afrikaner Broederbond: Belewinge van die binnekant, Lapa, Pretoria.

Stoop, J.A.A.A., 1984, 'Die vervloeking van Gam in Afrika', in J.A. Hofmeyr \& W.S. Vorster (eds.), New faces of Africa: Essays in honour of Ben (Barend Jacobus) Marais, pp. 153-164, Unisa, Pretoria.

Strauss, P., 2015, Gereformeerdes onder die Suiderkruis (1652-2011): Die verhaal van vier Afrikaanse kerke, SUN Press, Stellenbosch.

Tatum, W.B., 2009, Jesus: A brief history, Wiley-Blackwell, Chichester.

Terreblanche, S., 2014, Western empires, Christianity, and the inequalities between the West and the Rest 1500-2010, Penguin Books (South Africa), Johannesburg.

Times Books, 2006, The times history of Europe, HarperCollins, London.

Trocmé, É., 1997, The childhood of Christianity, SCM, London.

Van Oort, J., 2009, 'Augustinus en de Joden: Een inleidend overzicht', V\&E 30(1), 349 364, viewed 11 May 2018, from https://verbumetecclesia.org.za/index.php/ve/ article/view/78/64.

Vermes, G., 2013, Christian beginnings: From Nazareth to Nicaea, Yale University Press, New Haven, CT.

Veyne, P., 2010, When our world became Christian 312-394, Polity, Cambridge.

Welsh, D., 2010, The rise and fall of apartheid, Jonathan Ball, Jeppestown.

Wilkins, I. \& Strydom, H., 2012, The super-Afrikaners: Inside the Afrikaner Broederbond, Jonathan Ball, Cape Town. 